\title{
ROUNDTABLE SESSION 1 \\ THREATS TO INDIGENOUS CRAYFISH POPULATIONS - STUDIES ON A LANDSCAPE LEVEL
}

\author{
R. SCHULZ (1), H.K. SCHULZ (2)
}

(1) Institute for Environmental Sciences, University Koblenz-Landau, Im Fort 7, D-76829 Landau, Germany.

E-mail : R.Schulz@uni-landau.de

(2) Zoological Institute, Technical University, Fasanenstrasse 3, D-38092 Braunschweig, Germany.

E-Mail: $\underline{\text { R.Schulz@tu-bs.de }}$

\begin{abstract}
The present paper summarizes the outcome of a round-table discussion on landscape-level perspectives on threats to indigenous European crayfish populations, which took place during the CRAYNET Conference in Halden, Norway in September 2003.

A comparison of threats to European indigenous crayfish indicated that land-use is considered as the second most important impact on crayfish after non-indigenous species. It became furthermore evident that the main crayfish distribution data and land-use data are readily available in many European countries. They even exist as georeferenced data in data formats usable with Geographical Information Systems (GIS). In spite of this situation, it is rather surprising that there is only one case study available that attempted to link land-use data with crayfish presence on a landscape level. As a result of this study, GIS proved a suitable tool for the assessment of land-use effects and overall human impact on crayfish distribution on a landscape level.
\end{abstract}

Key-words: Conservation, freshwater decapod, GIS, land-use, management, indigenous crayfish, protection, stress, threats.

\section{MENACES SUR LES POPULATIONS D'ÉCREVISSES INDIGÈNES : ÉTUDE À L'ÉCHELLE DU PAYSAGE}

\section{RÉSUMÉ}

Cet article résume les conclusions d'une table ronde menée au cours de la conférence CRAYNET (Halden, Norvège, septembre 2003) et ayant pour sujet les perspectives offertes par l'étude du paysage sur les menaces exercées sur les populations d'écrevisses indigènes en Europe.

Une comparaison des menaces pesant sur les populations d'écrevisses indigènes en Europe montre que l'occupation des sols est considérée comme ayant le second impact le plus important après l'introduction des espèces non-indigènes. II était en outre évident que la plupart des données sur la distribution des écrevisses ainsi que celles sur l'occupation des sols sont déjà disponibles dans beaucoup de pays européens. Ces données existent souvent en tant que données géo-référencées dans des bases de données utilisables avec un Système d'Information Géographique (SIG). Cependant, il est 
plutôt surprenant de constater qu'il n'y a qu'une seule étude à ce jour qui tente de lier les données concernant l'occupation des sols et la présence des populations d'écrevisses à l'échelle du paysage. Selon cette étude, le SIG s'avère être un outil convenable pour évaluer les effets de l'occupation des sols et tout particulièrement l'impact des activités anthropiques sur la distribution des populations d'écrevisses.

Mots-clés: Conservation, décapode d'eau douce, SIG, occupation des sols, gestion, écrevisses indigènes, protection, stress, menaces.

\section{INTRODUCTION}

Various factors have been identified affecting the distribution and abundance of indigenous European crayfish (LAURENT, 1997; SKURDAL, 1995). Many of these factors are either directly or indirectly linked with geographical parameters and it appears thus vital to assess threats to crayfish on a landscape level. However, there is still considerable uncertainty as to how environmental factors actually affect crayfish on a landscape level and what questions should be answered with respect to conservation and management.

Landscape studies were defined as studies concerning areas large enough to draw conclusions on the landscape level. This rather fuzzy definition should account for the fact that even a study of one river (sub)catchment may be considered as a landscape study given that it involves a sufficient number of sites covering an area large enough to represent different land-use and thus different environmental factors. On the other hand, a landscape level study may involve a number of isolated lakes covering a wide geographical range and even different European eco-regions. Generally, the number of sites involved should be high enough to draw statistically sound conclusions. It is furthermore assumed that a landscape as an ecological unit contains metapopulations of crayfish and thus also contains the various levels of biological complexity such as the genetic, individual, population, community and ecosystem level. It is also important to note that crayfish are not only influenced by the landscape and the associated habitat features, they also have vice versa an impact on these features and thus influence the habitats they are occupying (HART, 1992; NYSTRÖM et al., 1999).

The objective of the present paper is to summarize current information on threats to indigenous crayfish in Europe, the availability of landscape-level data and case studies relating landscape or habitat features with crayfish occurrence. This summary is done in the view of a round-table discussion on the same topic, which was held during the CRAYNET conference in Halden, Norway in September 2003. Many countries may not be covered in this overview simply because there was no or only insufficient information available during the roundtable discussion. The rating of parameters or other information included is based on subjective estimates made by the experts attending the roundtable discussion.

\section{THREATS TO INDIGENOUS CRAYFISH IN EUROPE}

The most commonly considered threats to European indigenous crayfish are summarized in Table I. The results are presented according to eco-regions of Europe and more detailed national information were included, if available, for some of the eco-regions. It is obvious from Table I that crayfish plague and non-indigenous crayfish species play a major role as threats. The continued spread of non-indigenous Orconectes limosus (Raf.) is a major concern for example in Poland (STRUZYNSKI and SMIETANA 1999). Knowledge about the importance of other diseases seems to be rarely available due to the lack of competence or to the fact that health parameters are hardly included in governmental or academic monitoring programs (EDGERTON, 2002). Habitat management related 
parameters such as predators, exploitation and habitat alterations seems to have an intermediate importance as stressors. However, habitat alterations are considered as very important in Germany (SCHULZ, 2000) and illegal exploitation due to illegal trading and export of crayfish is a major problem in Estonia (HURT et al., 1999). Water level reductions due to abstraction of irrigation water seem to have only regional importance in some Mediterranean countries. As damming is not regulated in Latvia, this results sometimes in drying out of habitats posing a threat to local crayfish populations.

There was general conclusion that nutrients and the related eutrophication phenomena are largely of minor importance with exception of Poland (Table I). Acidification

\section{Table I}

Importance of various threats to indigenous crayfish populations among different ecoregions or countries of Europe $(1=$ low; 2 = medium; 3 =high; $?=$ no information). The listed relevant species refer to those species, for which the given information is most relevant, which not necessarily equals the whole list of species present in a given region (AUP = Austropotamobius pallipes; AUT = Austropotamobius torrentium; ASA = Astacus astacus).

\section{Tableau I}

Importance des diverses menaces sur les populations indigènes d'écrevisses parmi différents écorégions ou pays d'Europe $(1=$ faible ; $2=$ moyen ; 3 = important ; ? = aucune information). Les espèces significatives énumérées se réfèrent aux espèces pour lesquelles l'information fournie est la plus appropriée, ce qui ne correspond pas nécessairement à la liste entière des espèces actuellement présentes dans une région donnée (AUP $=$ Austropotamobius pallipes ; AUT = Austropotamobius torrentium ; ASA = Astacus astacus).

\begin{tabular}{|c|c|c|c|c|c|c|c|c|c|}
\hline \multirow[b]{2}{*}{ Threat } & \multirow[b]{2}{*}{ Alpine } & \multicolumn{2}{|c|}{ Atlantic } & \multicolumn{2}{|c|}{ Central } & \multirow{2}{*}{$\begin{array}{c}\text { Eastern } \\
\text { Estonia/ } \\
\text { Latvia }\end{array}$} & \multicolumn{2}{|c|}{ Mediterranean } & \multirow{2}{*}{$\begin{array}{l}\text { Scandi- } \\
\text { navian }\end{array}$} \\
\hline & & France & $\begin{array}{l}\text { Ireland/ } \\
\text { Wales }\end{array}$ & Germany & Poland & & Italy & Portugal & \\
\hline Crayfish plague & $2 / 3$ & 3 & $1 / 2$ & 2 & 1 & 2 & 1 & 3 & 3 \\
\hline Other diseases & $?$ & $?$ & 1 & $?$ & 1 & $?$ & $?$ & $?$ & $?$ \\
\hline $\begin{array}{l}\text { Non indigenous } \\
\text { species }\end{array}$ & $2 / 3$ & 3 & $1 / 2$ & 3 & 3 & 3 & 3 & 3 & 3 \\
\hline Predators & 1 & 1 & $1 / 2$ & 2 & 2 & 2 & 1 & 2 & 1 \\
\hline Exploitation & 1 & 1 & 1 & $1 / 2$ & 1 & 3 & 2 & 2 & 1 \\
\hline $\begin{array}{l}\text { Habitat } \\
\text { alterations }\end{array}$ & 2 & $2 / 3$ & $1 / 2$ & 3 & 2 & 2 & 2 & 1 & 1 \\
\hline $\begin{array}{l}\text { Water level } \\
\text { reductions }\end{array}$ & 1 & $2^{1}$ & 1 & $1 / 2$ & 2 & 2 & 1 & 3 & 1 \\
\hline Eutrophication & 2 & 1 & 1 & $1 / 2$ & 3 & 2 & 1 & 1 & $1 / 2$ \\
\hline Acidification & 1 & 1 & 1 & 1 & 1 & 1 & 1 & 1 & $1 / 2$ \\
\hline Toxicants & $2 / 3$ & 3 & $1 / 3$ & $?$ & $2 / 3$ & 3 & 3 & 2 & 1 \\
\hline Landuse & $2 / 3$ & 3 & $2 / 3$ & 3 & 2 & 3 & 2 & 3 & 2 \\
\hline Fragmentation & 3 & 3 & 1 & 3 & 1 & 3 & 2 & 1 & 2 \\
\hline $\begin{array}{l}\text { Considered } \\
\text { species }\end{array}$ & $\begin{array}{l}\text { AUT, } \\
\text { ASA, } \\
\text { AUP }\end{array}$ & AUP & AUP & ASA & ASA & ASA & AUP & AUP & ASA \\
\hline
\end{tabular}

\footnotetext{
1 Relevant for the Mediterranean region of France.
} 
on the other hand is only an issue in Scandinavia with the exception of Denmark. There are several publications confirming a relative wide range of general water-quality parameters and habitat requirements acceptable to indigenous crayfish (e.g. BOHL, 1999; GARCIAARBERAS and RALLO, 2000). Other toxicants, however, are considered as being of high importance as a stressor to crayfish, which is surprising given the almost complete lack of any field data linking the presence of toxicants with crayfish distribution or dynamics. Some recent studies from Wales seem to indicate a relation between pesticide contamination due to sheep dipping and effects on crayfish stocks. The same applies to land-use, which is according to Table I the second important threat to European crayfish, and yet has hardly been investigated so far. It appears thus quite challenging to investigate the relation between land-use and crayfish stocks a bit further and in doing so emphasizing the importance of landscape level approaches in future crayfish research. Another aspect closely linked with land-use is habitat fragmentation, the geographical isolation of crayfish habitats. Recent stocks often occur in small isolated lakes (SCHULZ, 2000) or isolated stretches of small rivers (ALONSO et al., 2000). Ironically, the presence of weirs and dams in running-water habitats seems to be favourable to indigenous crayfish stocks, because it prevents non-indigenous species or predatory fish from upstream distribution (BOHL, 1987). One general aspect, often associated with the geographical isolation of a surface water, is the absence or low degree of human impact such as fishing pressure by anglers or commercial fishermen, swimming activity or aquarium owners releasing non-indigenous crayfish (SKURDAL, 1995; DEHUS et al., 1999).

\section{LANDSCAPE-LEVEL DATA AVAILABILITY}

Considering the above-mentioned importance of landscape-related parameters such as land-use or habitat fragmentation, it seems to be reasonable to summarize the respective data available in different European countries (Table II). While information on the distribution (presence/absence) of indigenous crayfish species is largely available as point data, there is not much quantitative information on stock densities or health status. Information on non-indigenous crayfish species is also available as point or grid data in many European countries. It thus seems that our information about the presence and distribution of various crayfish species is relatively good and there remains a question as to what quality of environmental data is available on the landscape level.

Data on land-use exists in a Geographical Information System (GIS) format in Austria, France, Germany, and Ireland and is under preparation for Poland. Point or grid data on land-use is available e.g. for Estonia, Italy, Sweden, and Wales. Information on water quality (mainly trophic status) and morphological structures in surface waters is largely available as point or grid data. Most of these data result from governmental monitoring programs and it is assumed that the results from country-wide assessments of morphological structures in medium-size and large rivers in Germany will be available electronically in due course. Water quality and morphological structure information is collected in France on a regional level.

It can be concluded that for many countries the most important information such as crayfish distribution and land-use is readily available and it should thus be possible to link the two in order to derive conclusions on a landscape level.

\section{CASE STUDIES}

Spatial analysis of landscape patterns has been employed for the assessment of aquatic habitat quality since the end of the 1980s (OSBORNE and WILEY, 1988; JOHNSTON et al., 1990; RICHARDS and HOST, 1994). Although the number of studies in the open literature is still small, it has been stated quite often that land-use properties have 


\section{Table II}

Availability of landscape-level data on crayfish stocks, land use and habitat parameters among different countries of Europe (PD = point data; $G D=$ grid data; $\pm=$ only data for some regions; NA = not applicable; GIS = Geographical information System; $F G=$ Federal governments; $R G=$ Regional governments; EA = Environmental Agency; EPA = Environmental Protection Agency).

\section{Tableau II}

Disponibilité des données à l'échelle du paysage sur les stocks d'écrevisses, l'occupation des sols et les paramètres d'habitat dans différents pays d'Europe (PD = point de donnée ; $G D=$ Grille de Données ; $\pm=$ données uniquement pour quelques régions; $N A=$ Non Applicable ; $G I S=$ Système d'Information Géographique ; $\quad F G=$ Gouvernements Fédéraux ; $\quad R G=$ Gouvernements Régionaux ; $\mathrm{EA}=$ Agences Environnementales ; $\mathrm{EPA}=$ Agence de Protection de l'Environnement).

\begin{tabular}{|c|c|c|c|c|c|c|c|c|c|}
\hline Parameter & Austria & Estonia & France & Germany & Italy & Ireland & Poland & Sweden & $\begin{array}{c}\text { UK } \\
\text { (Wales) }\end{array}$ \\
\hline $\begin{array}{l}\text { Indigenous } \\
\text { crayfish } \\
\text { distribution }\end{array}$ & PD & PD & PD & PD & PD & PD & PD/GD & PD & PD \\
\hline $\begin{array}{l}\text { Indigenous } \\
\text { crayfish } \\
\text { densities }\end{array}$ & - & PD & - & \pm & - & \pm & \pm & \pm & PD \\
\hline $\begin{array}{l}\text { Indigenous } \\
\text { crayfish } \\
\text { diseases }\end{array}$ & - & PD & - & \pm & - & - & - & PD & GD \\
\hline $\begin{array}{l}\text { Non-indigenous } \\
\text { crayfish } \\
\text { distribution }\end{array}$ & PD & NA & PD & PD & PD & NA & GD & PD & GD \\
\hline Landuse & Corine (GIS) & PD & $\begin{array}{l}\text { Map } \\
\text { Info } \\
\text { (GIS) }\end{array}$ & $\begin{array}{l}\text { ATKIS } \\
\text { (GIS) }\end{array}$ & GD & GIS & GIS & PD & $\mathrm{PD} / \mathrm{GD}$ \\
\hline Water quality & $\begin{array}{l}\text { Major surface } \\
\text { waters }\end{array}$ & PD & \pm & PD & PD & PD & GD & PD & PD \\
\hline $\begin{array}{l}\text { Morphological } \\
\text { quality }\end{array}$ & $\begin{array}{l}\text { Major surface } \\
\text { waters }\end{array}$ & PD & \pm & PD & $\mathrm{PD} / \mathrm{GD}$ & PD & GD & $?$ & PD \\
\hline Data sources & $\mathrm{FG}, \mathrm{EA}$ & $\begin{array}{c}\text { RG, } \\
\text { Ministry of } \\
\text { Environment, } \\
\text { literature }\end{array}$ & $\begin{array}{c}R G, \\
\text { National } \\
\text { Fishery } \\
\text { Office }\end{array}$ & $F G$ & $\begin{array}{l}\text { RG, Unione } \\
\text { Zoologica } \\
\text { Italiana } \\
\text { (UZI) }\end{array}$ & $\begin{array}{c}\text { EPA, } \\
\text { literature }\end{array}$ & $\begin{array}{c}\text { FG, } \\
\text { literature }\end{array}$ & $\begin{array}{l}\text { RG, EPA, } \\
\text { National } \\
\text { Fisheries } \\
\text { Board }\end{array}$ & $\begin{array}{c}\text { EA, River } \\
\text { Habitat } \\
\text { Surveys, } \\
\text { literature }\end{array}$ \\
\hline
\end{tabular}

a strong impact on the aquatic community (SALLENAVE and DAY 1991; LENAT, 1994). Analysis of habitat requirements of crayfish has concentrated so far mainly on the water body and the shoreline of streams or lakes (Table III).

A large number of sites in Sweden was investigated between the 1950s and 1970s in order to link crayfish occurrence with $\mathrm{pH}$ (acidification) or eel (Anguilla anguilla L.) as a potential predator (SVÄRDSON, 1972, 1974). Data on the physical structure of several hundred river sites that were collected by the UK Environment Agency using the River Habitat Survey (RHS) methodology were used to assess the habitat requirements of the white clawed crayfish Austropotamobius pallipes (Lereboullet) (NAURA and ROBINSON 1998). Results showed that variables such as overhanging boughs, the presence of boulders, the amount of tree shading and the number of riffles have a positive impact on crayfish presence.

A total of 54 lakes in Estonia have been studied between 1993 and 1998 for the presence of the noble crayfish Astacus astacus (L.) (HURT et al., 1999). Oxygen 


\section{Table III}

Case studies from Europe trying to link crayfish data with habitat or landuse data.

Tableau III

Études de cas en Europe essayant de lier des données sur les écrevisses avec des données sur l'habitat ou sur l'occupation des sols.

\begin{tabular}{|c|c|c|c|}
\hline Region/Size & Methods & Results & Reference \\
\hline $\begin{array}{l}\text { Sweden ; 1950s-70s; } \\
\text { > } 1000 \text { sites }\end{array}$ & $\begin{array}{l}\mathrm{pH} \text { data and eel } \\
\text { presence related to } \\
\text { crayfish stocks }\end{array}$ & $\begin{array}{l}\text { Importance of } \mathrm{pH} \\
\text { and eel predation }\end{array}$ & $\begin{array}{l}\text { SVÄRDSON, } \\
\text { 1972; } 1974\end{array}$ \\
\hline $\begin{array}{l}\text { UK/Wales; about } \\
700 \text { river sites }\end{array}$ & $\begin{array}{l}\text { Habitat data related } \\
\text { to crayfish presence/ } \\
\text { absence data }\end{array}$ & $\begin{array}{l}\text { Importance of } \\
\text { channel vegetation } \\
\text { and bank and } \\
\text { channel structure }\end{array}$ & $\begin{array}{l}\text { NAURA and } \\
\text { ROBINSON, } \\
1998\end{array}$ \\
\hline Estonia; 54 lakes & $\begin{array}{l}\text { Trophic levels related } \\
\text { to crayfish presence }\end{array}$ & $\begin{array}{l}\text { No consistent } \\
\text { relationship }\end{array}$ & $\begin{array}{c}\text { HURT et al., } \\
1999\end{array}$ \\
\hline $\begin{array}{l}\text { S Tyrol; about } \\
150 \text { sites }\end{array}$ & $\begin{array}{l}\text { Historic and recent } \\
\text { data for landuse and } \\
\text { habitat related to } \\
\text { crayfish stocks }\end{array}$ & $\begin{array}{l}\text { Negative correlation } \\
\text { with habitat } \\
\text { degradation }\end{array}$ & $\begin{array}{l}\text { FÜREDER et al., } \\
2004\end{array}$ \\
\hline UK, 62 sites & $\begin{array}{l}\text { Habitat data related } \\
\text { to crayfish stocks }\end{array}$ & $\begin{array}{l}\text { Importance of } \\
\text { bank structure and } \\
\text { riparian vegetation }\end{array}$ & $\begin{array}{c}\text { SMITH et al., } \\
1996\end{array}$ \\
\hline Spain, 30 sites & $\begin{array}{l}\text { Physico-chemical } \\
\text { parameters related } \\
\text { to population } \\
\text { characteristics } \\
\end{array}$ & $\begin{array}{l}\text { Importance of } \\
\text { mineralization }\end{array}$ & $\begin{array}{c}\text { GARCIA-ARBERAS } \\
\text { and RALLO, } \\
2000\end{array}$ \\
\hline $\begin{array}{l}\text { S Germany (Bavaria); } \\
\text { about } 300 \text { sites }\end{array}$ & $\begin{array}{c}\text { Physico-chemical } \\
\text { parameters, } \\
\text { habitat data }\end{array}$ & $\begin{array}{l}\text { Negative correlation } \\
\text { with agriculture, } \\
\text { importance of water } \\
\text { quality, bank and } \\
\text { channel structure }\end{array}$ & BOHL, 1989 \\
\hline $\begin{array}{l}\text { NE Germany, NW } \\
\text { Poland; } 3 \times 100 \text { km²; } \\
\text { about } 90 \text { lake sites }\end{array}$ & $\begin{array}{l}\text { GIS-analysis of land } \\
\text { use related to } \\
\text { crayfish stocks }\end{array}$ & $\begin{array}{l}\text { Negative impact } \\
\text { of agriculture and } \\
\text { urban settlements }\end{array}$ & $\begin{array}{l}\text { SCHULZ et al. } \\
2002\end{array}$ \\
\hline
\end{tabular}

deficiencies caused by hard winters have been suggested as a potential reason for the observed decline in number of crayfish stocks. A negative impact of habitat degradation on A. pallipes has been reported from a study comprising historic and recent data from about 150 sites in south Tyrol (northern Italy) (FÜREDER et al., 2004). A comprehensive study of the status of $A$. astacus and its habitat situation in Bavaria (Germany) was conducted by BOHL (1989). Similarly, the habitat requirements of $A$. pallipes have been analysed in Britain and Spain (SMITH et al., 1996; GARCIA-ARBERAS and RALLO, 2000).

There may be more studies dealing with habitat requirements of crayfish, however, there are hardly any studies attempting to link landscape features with crayfish populations. By means of spatial analysis on the basis of a geographic information system (GIS), influence of land-use properties and other human impact on crayfish distribution was estimated in 92 lakes in northeast Germany and northwest Poland (SCHULZ et al., 2002). 
A. astacus was found only in lakes with a proportion of arable land below $10 \%$ within a $50 \mathrm{~m}$ buffer around the shoreline. Proportion of forest around these lakes was above the average for all lakes. In contrast, $O$. limosus appeared indifferent to all factors related to land use. Average lake size was clearly different for the two species. A. astacus was found in smaller lakes without direct contact to settled areas, whereas $O$. limosus preferentially inhabited larger lakes, indicating the importance of human activities in respect to extinction of indigenous crayfish stocks and propagation of non-indigenous crayfish species. GIS proved a suitable tool for the assessment of land-use effects and overall human impact on crayfish distribution on a landscape level. This is probably the only available study so far that used GIS to assess landscape features in relation to crayfish presence or absence.

\section{CONCLUSIONS}

Based on the fact that both crayfish distribution and land-use data are available in many European countries it is surprising to what extent we lack information on the relation between the two. Potential reasons might be that some key data are still missing or are not easy to obtain or that the scientific knowledge, interest or motivation to look further into this topic has not yet reached a critical mass. From the few case studies conducted so far it appears, however, that the investigation of crayfish in relation to land-use parameters on a landscape level, i.e. using GIS, can provide very helpful information for the protection and management of indigenous European crayfish species.

\section{ACKNOWLEDGEMENTS}

We gratefully acknowledge the contributions of Laura Aquiloni (Italy, with information for Portugal), Astra Cioni (Italy), Andréanne Demers (Ireland), Leopold Füreder (Austria), Francesca Gherardi (Italy), Frédéric Grandjean (France), Mererid Howells (UK), Margo Hurt (Estonia), Per Nyström (Sweden), and Galina Kanejeva (Latvia) to the roundtable discussion in Halden. Przemysław Smietana kindly provided information for Poland.

\section{REFERENCES}

ALONSO F., TEMINO C., DIEGUEZ-URIBEONDO J., 2000. Status of the white-clawed crayfish, Austropotamobius pallipes (Lereboullet, 1858), in Spain: Distribution and legislation. Bull. Fr. Pêche Piscic., 356, 31-54.

BOHL E., 1987. Crayfish stock and culture situation in Germany. Report from the Workshop on Crayfish Culture 16-19 November, Trondheim, Norway, 87-90.

BOHL E., 1989. Ökologische Untersuchungen an ausgewählten Gewässern zur Entwicklung von Zielvorstellungen des Gewässerschutzes: Untersuchungen an Flußkrebsbeständen. Bayerische Landesanstalt für Wasserforschung, Wielenbach, $237 \mathrm{p}$.

BOHL E., 1999. Crayfish stock situation in Bavaria - peculiar attributes, threats and chances. Freshwater Crayfish, 12, 765-777.

DEHUS P., PHILLIPSON S., BOHL E., OIDTMANN B., KELLER M., LECHLEITER S., 1999. German conservation strategies for native crayfish species with regard to alien species. In: GHERARDI F., HOLDICH D.M. (ed.), Crayfish in Europe as alien species, 149-159, A.A. Balkema, Rotterdam.

EDGERTON B., 2000. Hazard analysis of exotic pathogens of potential threat to European freshwater crayfish. Bull. Fr. Pêche Piscic., 367, 813-820.

FÜREDER L., OBERKOFLER B., HANEL R., LEITER J., THALER B., 2004. The freshwater crayfish Austropotamobius pallipes in South Tyrol: Heritage species and bioindicator. Bull. Fr. Pêche Piscic., 370-371, 81-95. 
GARCIA-ARBERAS L., RALLO A., 2000. Survival of natural populations of Austropotamobius pallipes in rivers in Bizkaia, Basque country (North of Iberian Peninsula). Bull. Fr. Pêche Piscic., 356, 17-30.

HART D.D., 1992. Community organization in streams: The importance of species interactions, physical factors, and chance. Oecologia, 91, 220-228.

HURT M., KIVISTIK M., PAAVER T., 1999. Changes in the state of noble crayfish stocks in lakes of Southern Estonia in the period 1993-1998. Freshwater Crayfish, 12, 540549.

JOHNSTON C.A., DETENBECK N.E., NIEMI G.J., 1990. The cumulative effect of wetlands on streamwater quality and quantity. A landscape approach. Biogeochemistry, 10, 105-141.

LAURENT, P.J., 1997. Crayfish introductions into France and in the world, history and consequences. Bull. Fr. Pêche Piscic., 347, 345-356.

LENAT D.R., CRAWFORD J.K., 1994. Effects of land use on water quality and aquatic biota of three North Carolina Piedmont streams. Hydrobiologia, 294, 185-199.

NAURA M., ROBINSON M., 1998. Principles of using River Habitat Survey to predict the distribution of aquatic species: an example applied to the native white-clawed crayfish Austropotamobius pallipes. Aquat. Conserv., 8, 515-527.

NYSTRÖM P., BRÖNMARK C., GRANÉLI W., 1999. Influence of an exotic and a native crayfish species on a littoral benthic community. Oikos, 85, 545-553.

OSBORNE L.L., WILEY M.J., 1988. Empirical relationships between land-use/cover patterns and stream water quality in an agricultural watershed. J. Environ. Manag., 26, 9-27.

RICHARDS C., HOST G., 1994. Examining land use influences on stream habitats and macroinvertebrates: a GIS approach. Water Res. Bull., 30, 729-738.

SALLENAVE R.M., DAY K.E., 1991. Secondary production of benthic stream invertebrates in agricultural watersheds with different land management practices. Chemosphere, 23, 57-76.

SCHULZ R. 2000. Status of the noble crayfish Astacus astacus (L.) in Germany: monitoring protocol and the use of RAPD markers to assess the genetic structure of populations. Bull. Fr. Pêche Piscic., 356, 123-138.

SCHULZ H.K., SMIETANA P., SCHULZ R., 2000. Crayfish occurrence in relation to landuse properties: Implementation of a Geographic Information System (GIS). Bull. Fr. Pêche Piscic., 367, 861-872.

SKURDAL J., 1995. Human impact on natural populations of European crayfish. Fauna (Oslo), 48, 134-143.

SMITH G.R.T., LEARNER M.A., SLATER F.M., FOSTER J., 1996. Habitat features important for the conservation of the native crayfish Austropotamobius pallipes in Britain. Biol. Conserv., 75, 239-246.

STRUZYNSKI W., SMIETANA P., 1999. On the distribution of crayfish in Poland. Freshwater Crayfish, 12, 825-829.

SVÄRDSON G., 1972. The predatory impact of eel (Anguilla anguilla L.) on populations of crayfish (Astacus astacus L.) Institute of Freshwater Research, Drottningholm.

SVÄRDSON G., 1974. Översikt över laboratoriets verksamhet med plan för år 1974 Institute of Freshwater Research, Drottningholm. 